\title{
Day and night grazing by cattle in the Sahel
}

\author{
AUgustine. A. AYANTUNDe, SALVAdor FERNÁNDEZ-RIVERA, PIERRE. H. HiERNAUX, \\ HERMAN VAN KEULEN, AND HENK M. J. UDO
}

Authors are former graduate Fellow, Animal Scientist and Range Ecologist, International Livestock Research Institute, ILRI/ICRISAT, B.P. 12404, Niamey, Niger, professor and Associate Professor, Animal Production Systems Group, Wageningen Agricultural University, P.O. Box 338, 6700 AH Wageningen, The Netherlands. The correspondence author is Henk Udo.

\begin{abstract}
The influence of night grazing on feeding behavior, nutrition and performance of cattle was studied. Twenty-four steers weighing $367 \mathrm{~kg}(\mathrm{SD}=76)$ grazed either from 0900 to 1900 (day grazers), 2100 to 0700 (night grazers) or 0900 to 1900 and 2400 to 0400 (day-and-night grazers) during 13 weeks. Four esophageally fistulated steers were used in a cross-over design to sample the diet selected during the day and at night. No differences $(P>$ 0.05) were observed in the diet selected in the day or at night. As the season progressed the fiber components of the diet increased $(P<0.01)$ significantly while nitrogen and in sacco dry matter disappearance declined $(P<0.01)$. Actual grazing time (min day ${ }^{-1}$, $\mathrm{SE}=16$ ) were 352,376 , and 476 for day, night, and day-and-night grazers, respectively. Day-and-night grazers had a higher intake of organic matter than either day or night grazers. Night grazers had the lowest forage intake and also the slowest rate of consumption. Steers that grazed in the night had the lowest water

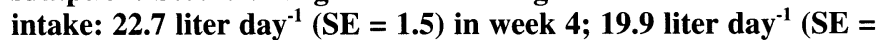
$1.1)$ in week 8. Average weight changes $\left(\mathrm{g} \mathrm{day}^{-1}, \mathrm{SE}=62\right)$ were $435,-548$ and -239 for day, night, and day-and-night grazers, respectively. These results show that during the dry season, grazing exclusively in the night cannot substitute for day time grazing, but that it is rather complementary to the latter. Timing (day or night) of grazing did not affect diet selection but nocturnal grazing decreased the need for water.
\end{abstract}

Key Words: cattle, forage intake, night grazing, Sahel

Night grazing is a common herd management practice in the West African Sahel, especially at the end of the dry season (Dicko-Tourè 1980, Powell et al. 1996). This practice has also been reported for herded animals in the sub-humid zone of West Africa (Bayer 1986), East Africa (Wigg and Owen 1973, Nicholson 1987) and for free ranging sheep and cattle in the USA and Australia (Vallentine 1990). In addition to the advantage of increased grazing time, King (1983) reported that night grazing helps to reduce heat stress on the animals and may increase forage intake. It has the benefit of manure deposition on rangelands rather than in the enclosed sites (Wigg and Owen 1973). However, this is in conflict with the practice of corralling the animals on cropland for depositing manure (Powell et al. 1996). Previous research (Fernández-Rivera et al. 1996) on night grazing

\footnotetext{
Manuscript accepted 7 Jul. 01.
}

\section{Resumen}

El objetivo del presente trabajo fue estudiar la influencia del pastoreo nocturno sobre el comportamineto alimenticio, el consumo de forraje, la excreción fecal y los cambios de peso en bovinos. Veinticuatro novillos con un peso inicial de $367 \mathrm{~kg}$ (desviación est·ndar $=76$ ) pastorearon de 0900 a 1900 (pastoreo diurno), 2100 a 0700 (pastoreo nocturno) o de 0900 a 1900 y de 2100 a 0700 (pastoreo dìa y noche) durante 13 semanas. Cuatro novillos con fìstula esof-gica fueron utilizados en un diseò reversible para muestrear la dieta seleccionada durante el dìa y en la noche. No se observaron diferencias $(P>0.05)$ en la dieta seleccionada en el dìa o en la noche. A medida que la estación seca avanzó los componentes de fibra de la dieta aumentaron ( $P$ $<0.01$ ), mientras que el contenido de nitrógeno y la desaparición in sacco de la materia seca disminuyeron $(\mathrm{P}<0.01)$. El tiempo de pastoreo propiamente dicho (i.e. tiempo de consumo) fue 352, 376 y 476 min dìa $^{-1}(\mathrm{SE}=16)$ para novillos con pastoreo nocturno, pastoreo diurno o con pastoreo el dìa y la noche, respectivamente. Los novillos con pastoreo el dìa y la noche tuvieron un mayor consumo de materia org-nica que aquellos que pastoreoran el dìa o la noche. Los novillos con pastoreo nocturno tuvieron los niveles y tasas de consumo de forraje $\mathrm{m} \cdot \mathrm{s}$ bajos. El consumo de agua fue tambiĚn $\mathrm{m} \cdot \mathrm{s}$ bajo en los novillos que pastorearon durante la noche 22.7 liter dìa ${ }^{-1}(\mathrm{SE}=1.5)$ en la semana 4 y 19.9 liter dÌa $^{-1}(\mathrm{SE}=4)$ en la semana 8). El cambio promedio de peso fue $-435,-548 \mathrm{y}-239 \mathrm{~g} \mathrm{dìa}^{-1}(\mathrm{SE}=62$ ) para los novillos con pastoreo nocturno, pastoreo diurno o con pastoreo el dìa y la noche, respectivamente. Estos resultados indican que durante la estación seca el pastoreo exclusivamente durante la noche no puede ser substituto, sino $\mathrm{m} \cdot \mathrm{s}$ bien complemento del pastoreo durante el dia. El momento (dÌa o noche) de pastoreo no affectó la selección de la dieta, pero el pastoreo nocturno disminuyó el requerimiento de agua.

by cattle showed that diet selection during the day and at night were not different. However, the steers that grazed during the day consumed more forage and water than those that grazed in the night. Further studies on the influence of night grazing on feeding behavior, nutrition and performance of cattle are needed to improve understanding of the nutrition of grazing cattle and cattle's role in nutrient transfer processes in the landscape.

The objective of this study was to determine the effects of night grazing on diet selection, forage and water intake, fecal excretion, feeding behavior and performance of cattle. 


\section{Material and Methods}

\section{Study site}

The experiment was conducted over 13 weeks at the end of the dry season (February to May) of 1995 at International Crop Research Institute for the Semi-Arid Tropics (ICRISAT-SC) in Sadorè (13० $14^{\prime}$ $\left.\mathrm{N} 2^{\circ} 16^{\prime} \mathrm{E}\right)$, Niger.

\section{Treatments, pasture and animals}

Twenty-four intact steers with a body weight $(\mathrm{W})$ of $367(\mathrm{SD}=76) \mathrm{kg}$ were randomly allotted to 3 treatments: grazing either from 0900 to 1900 (day grazing), 2100 to 0700 (night grazing) or 0900 to 1900 and 2400 to 0400 (day-and-night grazing). After return from the pasture, the steers were kept in individual pens in a barn located $150 \mathrm{~m}$ from the paddock. The animals grazed the same pasture in the day and at night, i.e. a fallow of 5.5 ha, dominated by annual grasses mainly Ctenium elegans Kunth, Diheteropogon hagerupii Hitchc., Pennisetum pedicellatum Trin. and forbs mainly Borreria stachydea (DC.) Hutch. \& Dalz. and Hibiscus sabdarifa Linn. At the beginning of the trial, the standing herbage and litter mass of the pasture were estimated at 828 and 1,070 kg DM ha ${ }^{-1}$, respectively (Table 1 ). The herbage mass consisted of standing hay composed of $59 \%$ grasses and $41 \%$ forbs.

The study included 2 periods of collection of feces and extrusa which started in weeks 4 and 8 of the experiment. Each period included 9 days of fecal collection.The animals were accustomed to carrying fecal collection bags during the last week before the collection started. In each collection period, fecal bags were emptied and the feces weighed, before and after grazing. Ten percent of the fecal excretion was sampled and frozen for subsequent analysis. Water intake was also measured in weeks 4 and 8 of the trial. All the animals were watered in the morning (0800) before grazing started. Water intake was measured daily during the collection periods, for which all animals had access to

Table 1. Nutritional quality of standing herbage and litter mass at the beginning of the experiment (March 1995).

\begin{tabular}{lccc}
\hline \hline Component & Standing herbage & Litter & SE \\
\hline & --- g kg $^{-1}$ DM & 938 & 6 \\
Organic matter & 949 & 3.4 & 0.5 \\
Nitrogen & 3.5 & 1.1 & 0.2 \\
Phosphorus & 1.2 & 412 & 18 \\
Dry matter digestibility & 426 & 391 & 19 \\
Organic matter digestibility & 400 & 367 & 13 \\
Digestible organic matter & 380 & &
\end{tabular}

water for $30 \mathrm{~min}$. In week 8 of the experiment the grazing activities of all steers were observed. Observation was made every $5 \mathrm{~min}$ ( 24 hour/day) for 3 consecutive days by 6 observers. The observation was instantaneous and the recording included one of the following activities: searching for food, prehending, masticating, ruminating, walking, drinking, sleeping, and idling. Grazing time was defined as the time spent prehending, masticating and searching for food. Idling included time spent neither for grazing, ruminating, sleeping, walking, nor drinking. Activities such as drinking, fighting, and socializing were referred to as 'other'.

In the 2 collection periods, four esophageally fistulated steers were randomly grouped into 2 pairs and were used in a cross-over design for sampling the diet selected during the day and at night. The 2 pairs either grazed in the day $(0900$ to 1900$)$ or at night (2100 to 0700$)$. During the data collection period in weeks 4 and 8 , samples of the diet selected by the fistulated steers (extrusa) were collected in the morning (1000) and afternoon (1500) for the day grazing pair, and at night (2200) and at dawn (0300) for the night grazing pair, for 3 consecutive days. At the end of the 3 days collection period, the 2 groups were switched. After switching the grazing schedule, the animals were allowed 3 days for adaptation after which extrusa samples were collected for another 3 days following the same collection schedule. The extrusa samples were frozen immediately after collection.

\section{Sample processing and laboratory analyses}

The daily fecal sub-samples were bulked by time of collection (before or after grazing) and analyzed for dry (DM) and organic matter $(\mathrm{OM})$. The extrusa samples were dried at $55^{\circ} \mathrm{C}$ for 48 hours and were ground to pass a $1-\mathrm{mm}$ screen. They were analyzed for DM, OM, nitrogen $(\mathrm{N})$, ashless neutral detergent fiber (NDF), ashless acid detergent fiber (ADF) 
Table 2. Chemical composition of forage selected (extrusa) by esophageally fistulated steers grazing in the day or at night.

\begin{tabular}{|c|c|c|c|c|c|}
\hline \multirow[b]{2}{*}{ Component } & \multicolumn{2}{|c|}{ Week 4} & \multicolumn{2}{|c|}{ Week 8} & \multirow[b]{2}{*}{ SE } \\
\hline & Day & Night & $\overline{\text { Day }}$ & Night & \\
\hline & & & $\overline{\mathrm{g} \mathrm{kg}^{-1}}$ & $-\cdots$ & -.- \\
\hline Organic matter & 894 & 883 & 881 & 889 & 4 \\
\hline Nitrogen & $9.0^{\mathrm{a}}$ & $8.1^{\mathrm{a}}$ & $7.5^{\mathrm{b}}$ & $7.1^{b}$ & 0.4 \\
\hline NDF & $649^{a}$ & $675^{\mathrm{a}}$ & $817^{\mathrm{b}}$ & $821^{b}$ & 6 \\
\hline $\mathrm{ADF}$ & $507^{\mathrm{a}}$ & $521^{\mathrm{a}}$ & $635^{\mathrm{h}}$ & $637^{b}$ & 6 \\
\hline Lignin & $134^{a}$ & $129^{\mathrm{a}}$ & $178^{\mathrm{b}}$ & $187^{\mathrm{b}}$ & 5 \\
\hline Cellulose & $373^{a}$ & $393^{\mathrm{a}}$ & $460^{b}$ & $450^{\mathrm{b}}$ & 6 \\
\hline Hemicellulose & $143^{x}$ & $154^{\mathrm{a}}$ & $182^{b}$ & $184^{\mathrm{b}}$ & 5 \\
\hline $\mathrm{DMD}^{2}$ & $533^{\mathrm{a}}$ & $524^{\mathrm{a}}$ & $486^{b}$ & $478^{\mathrm{b}}$ & 8 \\
\hline $\mathrm{OMD}^{2}$ & 469 & 455 & 459 & 444 & 8 \\
\hline $\mathrm{DOM}^{2}$ & 419 & 402 & 404 & 395 & 6 \\
\hline
\end{tabular}

Values with different superscripts denote significant difference $(\mathrm{P}<0.05)$ between means within rows.

${ }^{2} \mathrm{DMD}=$ Dry matter digestibility; OMD = Organic matter digestibility; and DOM = Digestible organic matter (i.e. OMD $\mathrm{x}$ OM).

6) of the diet selected by night grazers (675 $\mathrm{g} \mathrm{kg}^{-1} \mathrm{DM}$ ) was significantly higher than that of the day grazers $\left(649 \mathrm{~g} \mathrm{~kg}^{-1}\right.$ DM). As the dry season progressed (week 4 vs week 8 , Table 2) diet's NDF, ADF, cellulose, hemicellulose and lignin increased significantly $(P<0.01)$ while nitrogen concentration $(\mathrm{SE}=0.4)$ declined from 8.5 in week 4 to $7.3 \mathrm{~g} \mathrm{~kg}^{-1} \mathrm{DM}$ in week 8 and DMD $\left(\mathrm{g} \mathrm{kg}^{-1} \mathrm{DM}, \mathrm{SE}=8\right)$ also declined significantly (week $4=529$; week $8=482$ ).

Steers grazing in the day, night, and day-and-night spent 352,376 , and 476 min day ${ }^{-1}$ respectively for grazing (Table 3 ). Night grazers spent less time ruminating and walking than day grazers. Dayand-night grazers spent 124 minutes grazing more than day-grazers. The hourly distribution of time expenditure (Fig. 1.) for different activities showed that day grazers had 2 distinct grazing periods with the first in the morning till mid-day and the second before the sunset. The second grazing period accounted for over $60 \%$ of total time spent grazing. Day-and-night grazers also had 2 grazing periods in the day similar to day grazers with one additional period in the night of about 2 hours. Night grazers had 2 grazing periods with the initial period accounting for about $75 \%$ of the total grazing time. Steers that grazed in the day-and-night had lower time for resting (time spent sleeping + idling) than steers that grazed in the day (421 vs $560, \mathrm{SE}=$ $25, \mathrm{P}<0.05)$ but there was no difference in resting time by day grazers compared to night grazers (560 vs 614, $\mathrm{SE}=25)$.

Day, and day-and-night grazing steers consistently consumed more forage (g DM $\mathrm{kg}^{-0.75} \mathrm{~W}$ ) than steers that grazed at night (Table 4). In weeks 4 and 8, day-and-night grazers consumed daily 93.2 and $67.1 \mathrm{~g}$ DM $\mathrm{kg}^{-0.75} \mathrm{~W}$ respectively whereas night grazers consumed $62.5 \mathrm{~g} \mathrm{DM} \mathrm{kg}^{-0.75} \mathrm{~W}$ in week 4 and $53.6 \mathrm{~g} \mathrm{DM} \mathrm{kg}^{-0.75} \mathrm{~W}$ in week 8 . Day grazers consumed significantly more digestible organic matter (g DOM kg $\mathrm{kg}^{-0.75}$ W) than night grazers (Week 4: 30.2 vs 20.4, $\mathrm{SE}=1.6$; week $8: 22.7$ vs $18.3, \mathrm{SE}=$ 1.4), but the differences between day grazers and day-and-night grazers were not statistically significant. Forage intake declined significantly from week 4 to week 8 for day grazers, and day-and-night grazers. Intake rate $\left(\mathrm{mg} \mathrm{OM} \mathrm{kg}{ }^{-0.75} \mathrm{~W} \mathrm{~min}^{-1}\right)$ in week $8(\mathrm{SE}=7)$ were 142 for day grazers, 110 for night grazers and 113 for day-andnight grazers.

There was a significant difference in water intake between steers that grazed in
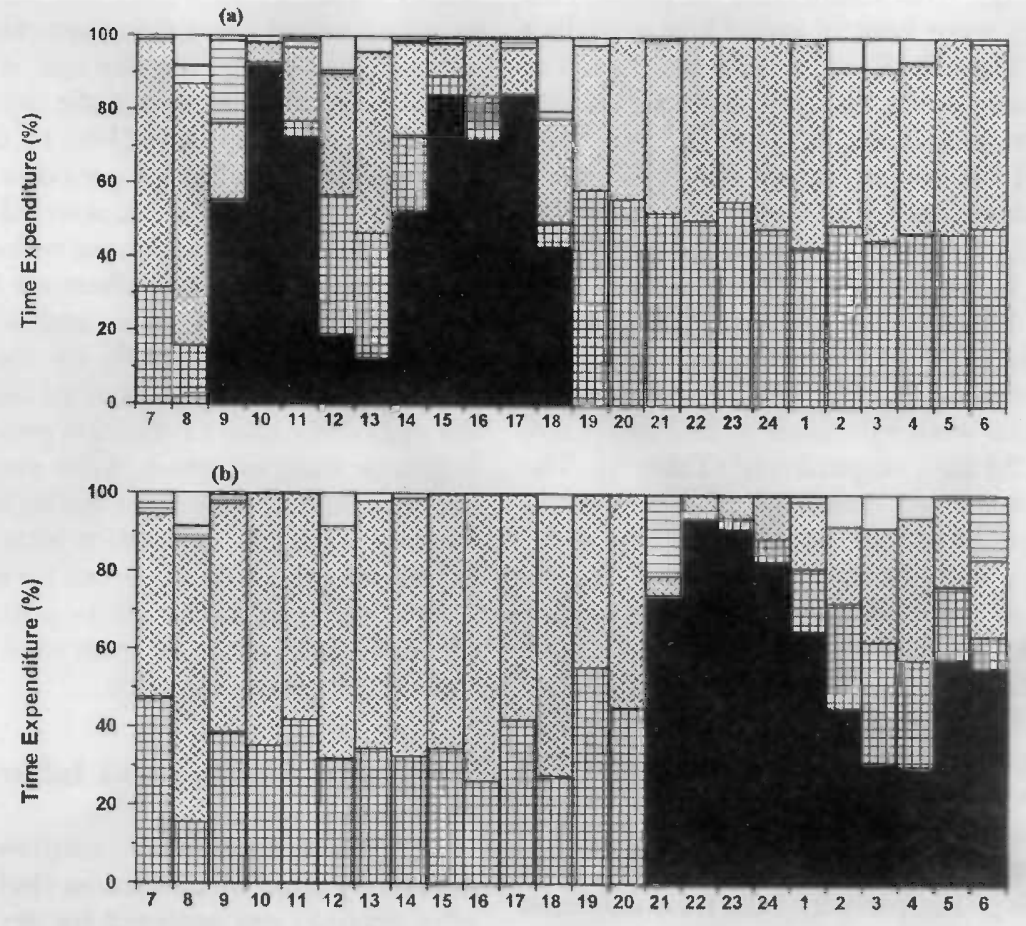

(c)

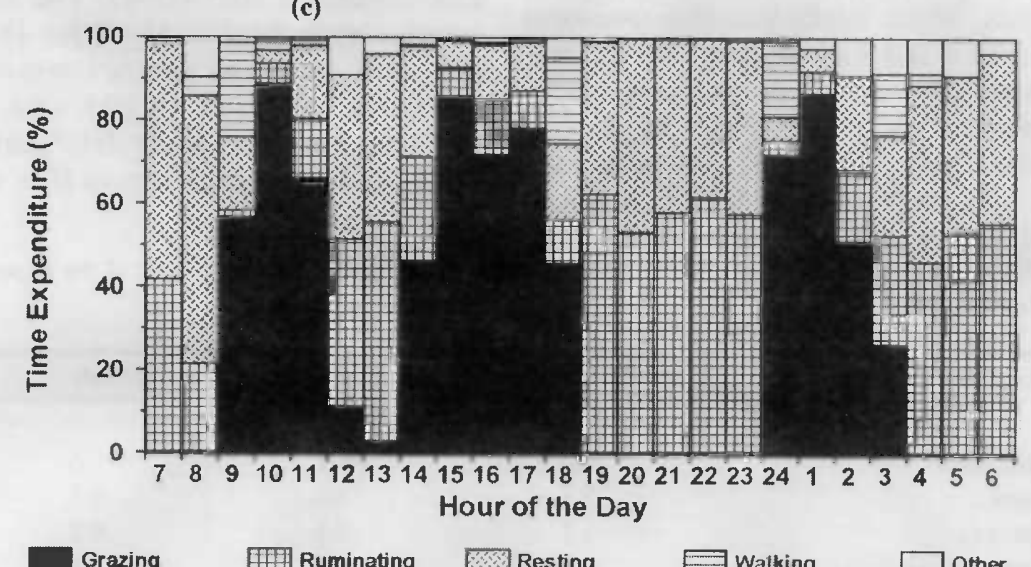

Grazing Euminating Walking

Other

Fig. 1. Hourly distribution of time expenditure for different activities by (a) day, (b) night, and (c) day-and-night grazing steers in the dry season in the Sahel. 
Table 3. Time expenditure on different activities in Week 8 (May 1995) of the experiment by day, night, and day-and-night grazing steers.

\begin{tabular}{lcccc}
\hline \hline Activity & Day & Night & Day-and-night & SE \\
\hline & $-12^{2}$ & $376^{\mathrm{a}}$ & $476^{\mathrm{b}}$ & 16 \\
Grazing $^{2}$ & $352^{\mathrm{a}}$ & $389^{\mathrm{b}}$ & $447^{\mathrm{a}}$ & 21 \\
Ruminating & $463^{\mathrm{a}}$ & $99^{\mathrm{a}}$ & $50^{\mathrm{b}}$ & 12 \\
Sleeping & $88^{\mathrm{a}}$ & $28^{\mathrm{a}}$ & $55^{\mathrm{b}}$ & 3 \\
Walking & $37^{\mathrm{a}}$ & $519^{\mathrm{a}}$ & $371^{\mathrm{b}}$ & 27 \\
Idling $^{2}$ & $472^{\mathrm{a}}$ & 29 & 43 & 10 \\
Other & 30 & 29 &
\end{tabular}

Values with different superscripts denote significant difference $(\mathrm{P}<0.05)$ between means within rows.

${ }^{2}$ Grazing includes prehension, mastication and search for food; Idling includes time spent neither for grazing, ruminating, sleeping, walking nor drinking; and Other includes activities such as drinking, fighting and socializing.

the night and those that grazed either in the day or in the day-and-night in both periods of measurement (Table 4). As the season progressed water intake of day grazers (week $4=35.5$, week $8=27.6$ liter day $^{-1}$ ) and day-and-night grazers (week 4 $=35.5$, week $8=27.6$ liter day $^{-1}$ ) declined significantly but that of night grazers (week $4=22.7$, week $8=19.9$ liter day $^{-1}$ ) remained fairly constant. Relative to forage intake water consumption (liter $\mathrm{kg}^{-1}$ forage DM) was constant for all treatments regardless of the period of measurement. Regression analyses of water intake on metabolic weight $\left(\mathrm{W}^{0.75}\right)$ and dry matter intake (DMI, $\mathrm{kg} \mathrm{DM}$ day $^{-1}$ ) showed that water intake $\left(\mathrm{ml} \mathrm{day}^{-1}\right)$ was correlated with metabolic weight in all treatments and and day-and-night grazers (equation 3 ) but not for night grazers (equation 2). The following regression equations were estimatwith DMI for day grazers (equation 1),

ed from the pooled data of weeks 4 and 8: water intake $=148(\mathrm{SE}=26) \mathrm{W}^{0.75}+$ $3243(\mathrm{SE}=343) \mathrm{DMI}\left(\mathrm{r}^{2}=0.99\right.$, $\mathrm{P}<0.01)$

water intake $=263(\mathrm{SE}=6) \mathrm{W}^{0.75}\left(\mathrm{r}^{2}=\right.$ 0.99, $\mathrm{P}<0.01$ )

water intake $=126(\mathrm{SE}=34)$

$\mathrm{W}^{0.75}+3412(\mathrm{SE}=429) \mathrm{DMI}$

$\left(\mathrm{r}^{2}=0.99, \mathrm{P}<0.01\right)$

In week 4 , fecal excretion by day grazers, night grazers, and day-and-night grazers were 9.3, 6.9, and $10.3 \mathrm{~g} \mathrm{DM} \mathrm{kg}^{-1} \mathrm{~W}$ day $^{-1}(\mathrm{SE}=0.7)$, respectively. In week 8 $(\mathrm{SE}=0.6)$, day grazers excreted 7.6 g DM $\mathrm{kg}^{-1} \mathrm{~W}$ day $^{-1}$, the fecal output by night grazers was $6.9 \mathrm{~g} \mathrm{DM} \mathrm{kg}^{-1} \mathrm{~W}$ day $^{-1}$ and day-and- night grazers voided $8.3 \mathrm{~g} \mathrm{DM}$ $\mathrm{kg}^{-1} \mathrm{~W}$ day $^{-1}$. A significant decrease in fecal excretion was observed in day grazers, and day-and-night grazers as the season progressed, whereas that of night graz-

Table 4. Daily intake of dry matter (DM), digestible organic matter (DOM) and intake rate, and water intake by day, night, and day-and-night grazing steers in the dry season in the Sahel.

\begin{tabular}{|c|c|c|c|c|}
\hline Variable & Day & Night & Day-and-night & SE \\
\hline \multicolumn{5}{|l|}{$\overline{\text { Week } 4}$} \\
\hline \multicolumn{5}{|l|}{ Forage intake } \\
\hline $\mathrm{g} \mathrm{DM} \mathrm{kg}^{-0.75} \mathrm{~W}$ & $86.3^{\mathrm{a}} \dagger$ & $62.5^{b}$ & $93.2^{\mathrm{a}}+$ & 4.8 \\
\hline $\mathrm{g} \mathrm{DOM} \mathrm{kg}^{-0.75} \mathrm{~W}$ & $30.2^{\mathrm{a}} \dagger$ & $20.4^{\mathrm{b}}$ & $31.9^{\mathrm{a}} \dagger$ & 1.6 \\
\hline \multicolumn{5}{|l|}{ Water intake } \\
\hline liter animal ${ }^{-1}$ day $^{-1}$ & $36.0^{\mathrm{a}} \dagger$ & $22.7^{b}$ & $35.5^{\mathrm{a}} \dagger$ & 1.5 \\
\hline liter $\mathrm{kg}^{-1}$ forage DM & $5.1^{\mathrm{a}}$ & $4.4^{b}$ & $4.9^{\mathrm{a}}$ & 0.2 \\
\hline $\mathrm{ml} \mathrm{kg}^{-1} \mathrm{~W}$ day $^{-1}$ & $100^{a_{+}}$ & $62^{b}$ & $105^{\mathrm{a} \dagger}$ & 5 \\
\hline \multicolumn{5}{|l|}{ Week 8} \\
\hline \multicolumn{5}{|l|}{ Forage intake } \\
\hline $\mathrm{g} \mathrm{DM} \mathrm{kg}^{-0.75} \mathrm{~W}$ & $62.9^{\mathrm{a}}$ & $53.6^{\mathrm{b}}$ & $67.1^{\mathrm{a}}$ & 4 \\
\hline $\mathrm{g} \mathrm{DOM} \mathrm{kg}^{-0.75} \mathrm{~W}$ & $22.7^{\mathrm{a}}$ & $18.3^{b}$ & $24.3^{\mathrm{a}}$ & 1.4 \\
\hline \multicolumn{5}{|l|}{ Intake rate } \\
\hline $\mathrm{g} \mathrm{DM} \min ^{-1}$ & $14.4^{\mathrm{a}}$ & $11.2^{\mathrm{b}}$ & $11.0^{\mathrm{b}}$ & 0.7 \\
\hline $\mathrm{mg}$ OM kg ${ }^{-0.75} \mathrm{~W} \min ^{-1}$ & $142^{a}$ & $110^{\mathrm{b}}$ & $113^{b}$ & 7 \\
\hline \multicolumn{5}{|l|}{ Water intake } \\
\hline liter animal ${ }^{-1}$ day $^{-1}$ & $27.1^{\mathrm{a}}$ & $19.9^{b}$ & $27.6^{\mathrm{a}}$ & 1.1 \\
\hline liter $\mathrm{kg}^{-1}$ forage DM & $5.5^{\mathrm{a}}$ & $4.8^{\mathrm{b}}$ & $5.3^{\mathrm{a}}$ & 0.3 \\
\hline $\mathrm{ml} \mathrm{kg}^{-1} \mathrm{~W}$ day $^{-1}$ & $80^{\mathrm{a}}$ & $59^{b}$ & $82^{\mathrm{a}}$ & 3 \\
\hline
\end{tabular}

${ }^{\mathrm{T}}$ Values with different superscripts denote significant difference $(\mathrm{P}<0.05)$ between means within rows.

${ }^{2}$ Different symbols $(\dagger)$ following the same variable in Weeks 4 and 8 within a treatment group (column) denote significant difference $(\mathrm{P}<0.05)$ between values in the 2 periods. ers remained essentially the same.

Average weight changes $\left(\mathrm{g} \mathrm{day}^{-1}, \mathrm{SE}=\right.$ 62) was -435 for day grazers, -548 for night grazers and -239 for day-and-night grazers. There was no significant difference in weight changes between day grazers and night grazers.

\section{Discussion}

The results on diet (extrusa) quality show that the time (day or night) of grazing had no significant influence on dietary selection, which supports the findings by Arnold (1966) that sight does not play a major role in the selection of plant parts by grazing animals. Similar results were observed by Fernández-Rivera et al. (1996). However, there may be differences between the quality of diet selected during the day and at night if the grazing sites and species composition are different, which is often the case when the animals are herded during night grazing. The declining quality of the diet selected as the season progressed, as observed in this study, has also been reported by Schlecht (1995) for steers and by Becker et al. (1996) for zebu cows grazing natural pastures in the region. Nitrogen concentration (7.1-9.0 g $\left.\mathrm{kg}^{-1} \mathrm{DM}\right)$ in the diet selected was similar to values reported in the dry season by Schlecht (1995) in Mali (53-82 $\mathrm{g} \mathrm{CP} \mathrm{kg}^{-1}$ OM) and Becker et al. (1996) in Niger (64 $-75 \mathrm{~g} \mathrm{CP} \mathrm{kg}^{-1} \mathrm{OM}$ ) for extrusa samples taken in the same season. The digestibility of OM (444 - $469 \mathrm{~g} \mathrm{~kg}^{-1} \mathrm{DM}$ ) was similar to that observed by the latter authors and by Fernández-Rivera et al. (1996) in the region.

Regardless of the time of grazing, the steers spent about $60 \%$ of the time allowed for grazing (i.e. prehension, mastication, and searching for food). The actual grazing times of 5.9, 6.3, and 7.9 hours for day, night, and day-and-night grazing, respectively, compare well with reported values in the dry season of 6.3 hours for a day grazing herd in Kenya by Coppock et al. (1988); 7 to 8 hours for day-and-night grazers in Uganda by Harker et al. (1954) and 7.4 to 10.4 hours reported by DickoTourè (1980) for day-and-night grazers in Mali. The ruminating time (6.5 to 7.7 hours) also agrees with those reported by Dicko-Tourè (1980) and Harker et al. (1954). Night grazers spent less time ruminating than either day grazers or day-andnight grazers, because they had a lower forage intake. This might also be associated with the natural inclination to ruminate in the night. The lower walking time for 
steers that grazed in the night compared to the other groups, even though they grazed in the same pasture, supports the findings of Arnold (1966) that sight impairment (poor visibility) causes orientation problems, which limits the area for selective grazing by the animals. The cost of grazing in the night in addition to day grazing is a reduction in resting time as observed for day-and-night grazers. The general pattern of 2 grazing periods during the day, separated by a mid-day rest observed in day grazers, and day-and-night grazers has also been reported by Coppock et al. (1988) for Turkana cattle in Kenya. Night grazers had a longer initial grazing period (4.5 vs 2.7 hours) than day grazers, probably because they were not constrained by heat and high radiation. Resting between the grazing periods by night grazers may likely be induced by rumen fill or fatigue. Similar findings were reported by Fernández-Rivera et al. (1996) in a preliminary study on nocturnal grazing by cattle in the region.

Forage intake, in both weeks 4 and 8 , was lower for night grazers than day grazers, which supports previous findings by Fernández-Rivera et al. (1996). This was due to a slow intake rate. Forage intake by day grazers $\left(64.6 \mathrm{~g} \mathrm{OM} \mathrm{kg}^{-0.75} \mathrm{~W}\right)$, and day-and-night grazers $(69.0 \mathrm{~g})$ in week 4 falls within the range of 63-83 g reported by Schlecht (1995) for unsupplemented steers in Mali and the values reported by Becker et al. (1996) for unsupplemented cows in Niger. The intake values in week 8 , however, are lower than those reported by these authors. Day-and-night grazers spent longer time grazing than day grazers but intake was not significantly different. This means that in the day-and-night grazing group, intake (and intake rate) during the day decreased due to night grazing. The fecal excretion values found in this study (6.3-11.0 $\mathrm{g} \mathrm{DM} \mathrm{kg}^{-1} \mathrm{~W}$ day $\left.^{-1}\right)$ is similar to those reported by Schlecht (1995). Collectable manure, i.e. the amount of feces excreted while not in the pastures (manure excreted while in the corralling site), was higher than the feces deposited in the rangelands by day grazers (week 4: 1,786 vs 1,521 , week $8: 1,322$ vs 1,236 $\mathrm{g} \mathrm{DM}$ animal $^{-1}$ day $^{-1}$ ). The reverse was the case for the animals that grazed in the night, i.e. night grazers (week 4: 1,058 vs 1,385 , week 8: 953 vs 1,304 g DM ani$\mathrm{mal}^{-1} \mathrm{day}^{-1}$ ) and day-and-night grazers (week 4: 1,126 vs 2,326, week 8: 932 vs $1,836 \mathrm{~g} \mathrm{DM}$ animal $^{-1}$ day $^{-1}$ ). This shows that more manure could be collected from animals that did not graze in the night compared to those that did. The amounts of collectable manure estimated in this study fall within the range of 600 to 1,500 $\mathrm{g} \mathrm{DM} \mathrm{TLU}^{-1}$ (TLU is Tropical Livestock Unit, animal of $250 \mathrm{~kg}$ body weight) reported by Khombe et al. (1992) and Fernández-Rivera et al. (1995).

Consumption of water relative to forage intake (liter $\mathrm{kg}^{-1}$ forage DM) found in this study agrees with the value of 4.5 liter kg-1 forage DM reported by King (1983). The day, and day-and- night grazers, that consumed more forage drank more water than the night grazers. High water consumption by the former could also be associated with high temperatures during the day, as reported by Nicholson (1987) and King (1983), the latter suggesting an extra water cost of 0.35 liter $\mathrm{km}^{-1}$ for walking in high solar heat. The range in water consumption (56-110 ml kg-1 $\mathrm{W}$ day ${ }^{-1}$ ) observed in this study is below the theoretical maximum $\left(160 \mathrm{ml} \mathrm{kg}^{-1} \mathrm{BW}\right.$ day $\left.^{-1}\right)$ suggested by King (1983) for cattle grazing tropical pastures. The lower water intake observed in the second period of measurement (week 8) could be attributed to an unexpected rainfall during the period and the concomittant fall in daily temperature for some days and the low ingestion of forage. Low water consumption by the night grazers observed in this study and the previous one (Fernández-Rivera et al. 1996) suggests that during a period of water scarcity, the water needs of grazing cattle could be reduced if nocturnal grazing is practiced without day grazing and the animals are restricted and protected from sunlight during the day.

Steers that grazed in the day-and-night had lower weight loss (239 $\left.\mathrm{g} \mathrm{day}^{-1}\right)$ than either day grazers $\left(435 \mathrm{~g} \mathrm{day}^{-1}\right)$ or night grazers $\left(548 \mathrm{~g} \mathrm{day}^{-1}\right)$. Similar results were reported by Wigg and Owen (1973) and Khombe et al. (1992) for steers that grazed day and night. These findings and that of the present study show that grazing exclusively in the night cannot substitute for day grazing. It rather complements day grazing and leads to better animal performance especially in the dry season. From the data on weight change and intake, day-andnight grazers lost significantly less weight than day grazers but had the same diet quality and intake, whereas day grazers had higher intake than night grazers but had the same weight loss. This discrepancy could be due to differential gut fill which might have influenced live weight measurement (t' Mannetje et al. 1976). The differential gut fill could be associated with the time of the day (0730 to 0800) at which all the animals were weighed. This implies that the night grazers were weighed almost immediately after grazing, about 4 hours after night grazing for dayand-night grazers and 12 hours after grazing for day grazers. Perhaps, the weight loss for night grazers and day-and-night grazers could have been higher than the reported values if they had been weighed at the same time difference after grazing as the day grazers. However, this is not feasible due to the experimental design.

The results also show that the traditional practice of night corralling (i.e. no night grazing) of cattle in West African Sahel put a nutritional stress on the animals (by decreasing forage intake), thereby increasing weight losses especially in the dry season. It also increases the needs for supplementation. To resolve the conflict between night grazing and night corralling, it is necessary to determine the optimum use of the animal's time for grazing and manuring. Therefore, further research on combinations of timing (day and/or night) and duration of grazing is needed to identify practical and feasible recommendations on how to resolve the conflict.

\section{Literature Cited}

Arnold, G.W. 1966. The special senses in grazing animals. I. Sight and dietary habits in sheep. Aust. J. Agr. Res. 17:521-529.

Bayer, W. 1986. Agropastoral herding practices and grazing behaviour of cattle in the subhumid zone of Nigeria. ILCA Bull. 24:8-13.

Becker, K., C. Gall, A. Susenbeth, and T. Rath. 1996. Nutrition and productivity of milking cattle on a semi-arid rangeland in West Africa, p. 153-184. In: Adapted farming in West Africa. Rep. on results, Interim Rep. 1994 - 1996; Special programme 308, Univ. Hohenheim, Hohenheim, Germany.

Coppock, D.L., J.E. Ellis, and D.M. Swift. 1988. Seasonal patterns of activity, travel and water intake for livestock in south Turkana, Kenya. J. Arid Environ. 14:319-331.

Dicko-Tourè, M.S. 1980. The contribution of browse to cattle fodder in the sedentary system of the Office du Niger, p. 313-319. In: H. N. Le HouÈrou (ed.), Browse in Africa: the current state of knowledge. International Livestock Center for Africa, Addis Ababa, Ethiopia.

Fernández-Rivera, S., A. Ayantunde, P.H.Y. Hiernaux, and M. Turner. 1996. Nocturnal grazing effects on the nutrition of cattle. J. Anim. Sci. 74 (Suppl. 1) 200 (abstr.).

Fernández-Rivera, S., T. O. Williams, P. Hiernaux, and J. M. Powell. 1995. Fecal excretion by ruminants and manure availability for crop production in semi-arid West Africa, p. 149-169. In: J. M. Powell, S. Fern-ndez-Rivera, T. O. Williams, and C. Renard (eds.), Livestock and sustainable nutrient cycling in mixed farming systems of 
sub-saharan Africa. Volume II: Technical papers. International Livestock Center for Africa, Addis Ababa, Ethiopia.

Harker, K.W., J.I. Taylor, and D.H.L. Rollinson. 1954. Studies on habits of zebu cattle. I. Preliminary observations on grazing habits. J. Agr. Sci. (Camb.). 44:193-198.

Khombe, C.T., I.A. Dube, and P. Nyathi. 1992. The effects of kraaling and stover supplementation during the dry season on body weight and manure production of Mashona steers in Zimbabwe. African Livestock Res. $1: 18-23$

King, J.M. 1983. Livestock water needs in pastoral Africa in relation to climate and forage. ILCA (International Livestock Center for Africa) Res. Rep. 7, Addis Ababa, Ethiopia.
t'Mannetje, L., R.J. Jones, and T.H. Stobbs. 1976. Pasture evaluation by grazing experiments, p. 194-234. In: Shaw N.H and W.W Bryan (eds.), Tropical pasture research: principles and methods.Commonwealth bureau of pastures and field crops, Hurley, Berkshire.

Nicholson, M.J. 1987. Effects of night enclosure and extensive walking on the productivity of zebu cattle. J. Agr. Sci. (Camb.). 109:445-452.

Powell, J. M., S. Fernández-Rivera, P. Hiernaux, and M.D. Turner. 1996. Nutrient cyling in integrated rangeland/cropland systems of the Sahel. Agr. Sys. $52: 143-170$
Schlecht, E. 1995. The influence of different levels of supplementation on feed intake and nutrient retention of grazing zebu cattle in Sahelian agro-pastoral systems. Ph.D Thesis, Univ. Hohenheim, Hohenheim, Germany.

Statistical Analysis System Institute. 1987. SAS/STAT guide for personal computers. SAS Institute Inc., Cary, N.C.

Vallentine, J.F. 1990. Grazing management Academic Press, San Diego, Calif.

Van Soest, P.J., J.B. Robertson, and B.A. Lewis. 1991. Methods for dietary fiber, and nonstarch polysaccharides in relation to animal nutrition. J. Dairy Sci. 74:3583-3597.

Wigg, P.M. and M.A. Owen. 1973. Studies on water consumption, night grazing and growth of Boran and crossbreed steers at Kongwa, Tanzania. East African Agr. and Fores. J. $38: 361-366$ 